\title{
Gestational Trophoblastic Neoplasm cM0 TNM Finding v8
}

National Cancer Institute

\section{Source}

National Cancer Institute. Gestational Trophoblastic Neoplasm CMO TNM Finding v8. NCI Thesaurus. Code C140018.

Gestational trophoblastic neoplasm without evidence of distant metastasis. (from AJCC 8th Ed.) 